\title{
The Direct Effect of Hypoglycaemic Sulphonylureas on Myocardial Contractile Force and Arterial Blood Pressure
}

\author{
G. Pogátsa and E. Dubecz \\ Research Unit, National Institute of Cardiology, Budapest, Hungary
}

Summary. The cardiovascular effects of glibenclamide, gliclazide and carbutamide were studied on myocardial contractile force, cardiac output, mean arterial pressure and heart rate in 43 intact, 14 pancreatectomized and 18 adrenalectomized dogs. It is shown that a positive inotropic and hypertensive effect of hypoglycaemic sulphonylureas develops without the mediation of glucagon, insulin or adrenaline. Contrary to the other investigated sulphonylureas, glibenclamide reduced myocardial contractile force and arterial blood pressure.

Key words: Glibenclamide, gliclazide, carbutamide, myocardial contractile force, cardiac output, arterial blood pressure, heart rate.

A positive inotropic and hypertensive effect of hypoglycaemic sulphonylureas has been confirmed by numerous authors $[3,5,9,10,11,15,17]$, but these studies did not make clear whether or not the drugs exert their cardiovascular effects directly. It is also disputed whether or not the sulphonylureas exert their cardiovascular effects in all species [5]. This study was undertaken, therefore, to evaluate the positive inotropic and hypertensive effect of hypoglycaemic sulphonylureas in intact and in pancreatectomized or adrenalectomized dogs.

The original and the more recently developed sulphonylureas are known to differ in certain effects [14]. Therefore, two of the newer preparations, glibenclamide and gliclazide, have been compared with one of the original compounds, carbutamide.

\section{Materials and Methods}

The experiments were performed in 75 mongrel dogs of both sexes, weighing $13-19 \mathrm{~kg}$. The animals were anaesthetized with chloralose $(100 \mathrm{mg} / \mathrm{kg})$ and fasted for twelve hours before the study. After opening the chest and the pericardium, myocardial contractile force was measured with a microdynamometer (Isometric transducer, Type DY-3) attached to the anterior wall of the left ventricle; mean arterial pressure directly by a Statham gauge (Type p23Db) in the femoral artery; cardiac output by an electromagnetic flowmeter (Nycotron, Type 372) placed on the aortic root; the rate of change of myocardial force by derivation of the microdynamometer curve; and peak acceleration of the aortic volume flow by derivation of the curve of pulsatile aortic volume flow. The curves were recorded by an Elema-Schönander Mingograph 81. After the initial surgery baseline estimates were carried out for up to $120 \mathrm{~min}$, and $45 \mathrm{~min}$ in the pancreatectomized or adrenalectomized dogs. Recording was continued thereafter from the beginning of drug administration until the end of drug effect, on average for fifteen minutes. The effects of the compounds were calculated from the most marked change and expressed in percent of the baseline values.

The substances were injected intravenously in two minutes in a volume of $1 \mathrm{ml} / \mathrm{kg}$ body weight. Glibenclamide (Gilemal, Chinoin) was given in doses of 0.2 and $1 \mathrm{mg} / \mathrm{kg}$, gliclazide (Diamicron, Servier) in doses of 5 and $15 \mathrm{mg} / \mathrm{kg}$, and carbutamide (Bucarban, Chinoin) in doses of 20 and 80 $\mathrm{mg} / \mathrm{kg}$. The possible intervention of insulin, glucagon or adrenaline was excluded by pancreatectomy (14 animals) and adrenalectomy (18 animals), respectively. The substances were given to the intact animals first in the lower and after this in the higher dose. After pancreatectomy and adrenalectomy the administered dose was in every case the higher one in order to enhance the changes. The cardiovascular effect of insulin given to intact animals was also 

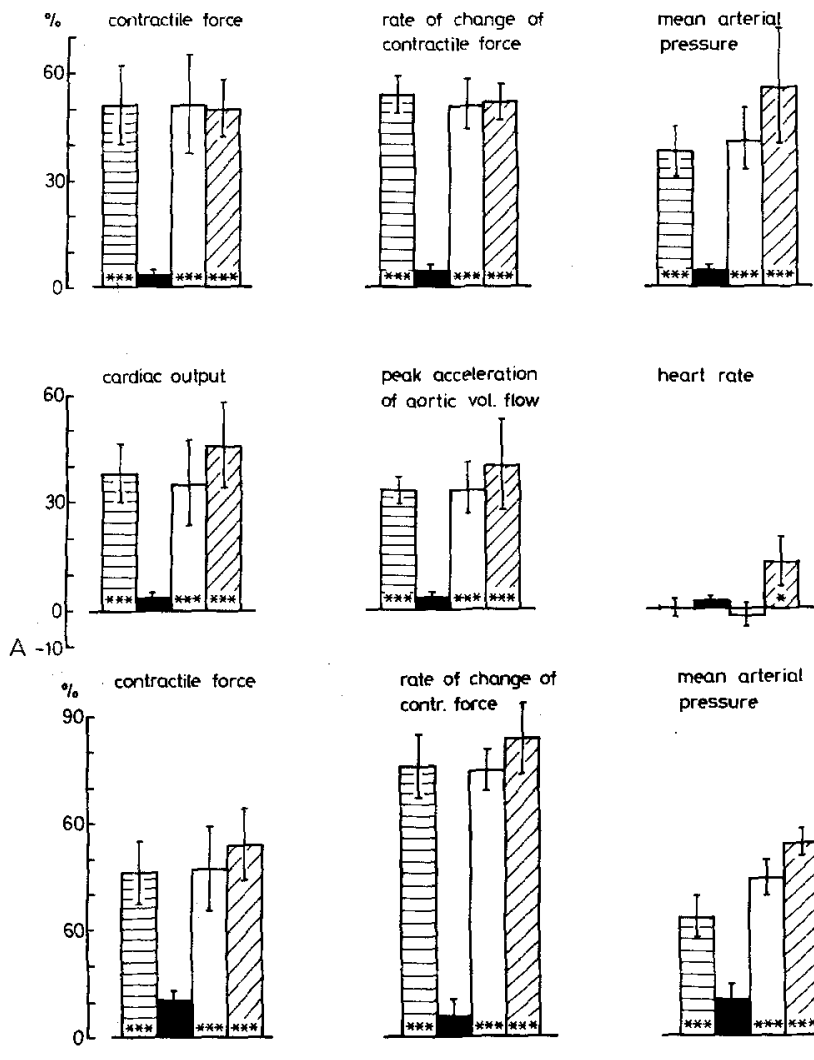

heart rate

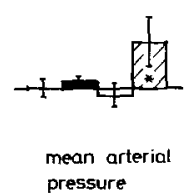

Fig. 1. Percentage change of myocardial contractile force, rate of change of contractile force, mean arterial pressure, cardiac output, peak acceleration of aortic volume flow and heart rate in intact dogs and in pancreatectomized and adrenalectomized animals on carbutamide, on gliclazide, on insulin and on the solvents of the drugs. In the part " $A$ " of the figure the horizontal lined columns indicate the mean values in intact animals after administration of $80 \mathrm{mg} / \mathrm{kg}$ carbutamide (n:7); black columns those in intact animals after administration of $1 \mathrm{ml} / \mathrm{kg}$ solvents ( $\mathrm{n}: 36$ ); blank columns those in pancreatectomized animals after administration of $80 \mathrm{mg} / \mathrm{kg}$ carbutamide ( $\mathrm{n}: 7$ ); and diagonally lined columns those in adrenalectomized animals after administration of $80 \mathrm{mg} / \mathrm{kg}$ carbutamide (n:8). In the part "B" of the figure the horizontal lined columns indicate the mean values in intact animals after administration of $15 \mathrm{mg} / \mathrm{kg}$ gliclazide (n:6); black columns those in intact animals after administration of $0.8 \mathrm{U} / \mathrm{kg}$ insulin (n:6); blank columns those in pancreatectomized animals after administration of $15 \mathrm{mg} / \mathrm{kg}$ gliclazide ( $\mathrm{n}: 7$ ); and diagonally lined columns those in adrenalectomized animals after administration of $15 \mathrm{mg} / \mathrm{kg}$ gliclazide (10). The vertical lines on the top of columns indicate the standard error of mean values. The de-
gree of significance of the difference from the solvent values is $B$ ol

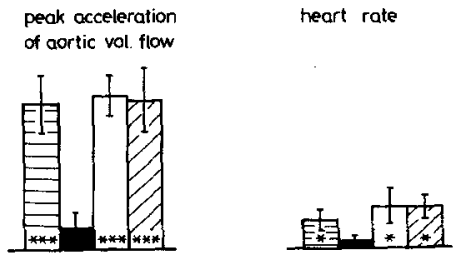
indicated by if ${ }^{*} \mathrm{p}<0.05$; if ${ }^{* *} \mathrm{p}<0.01$ and if ${ }^{* * *} \mathrm{p}<0.001$
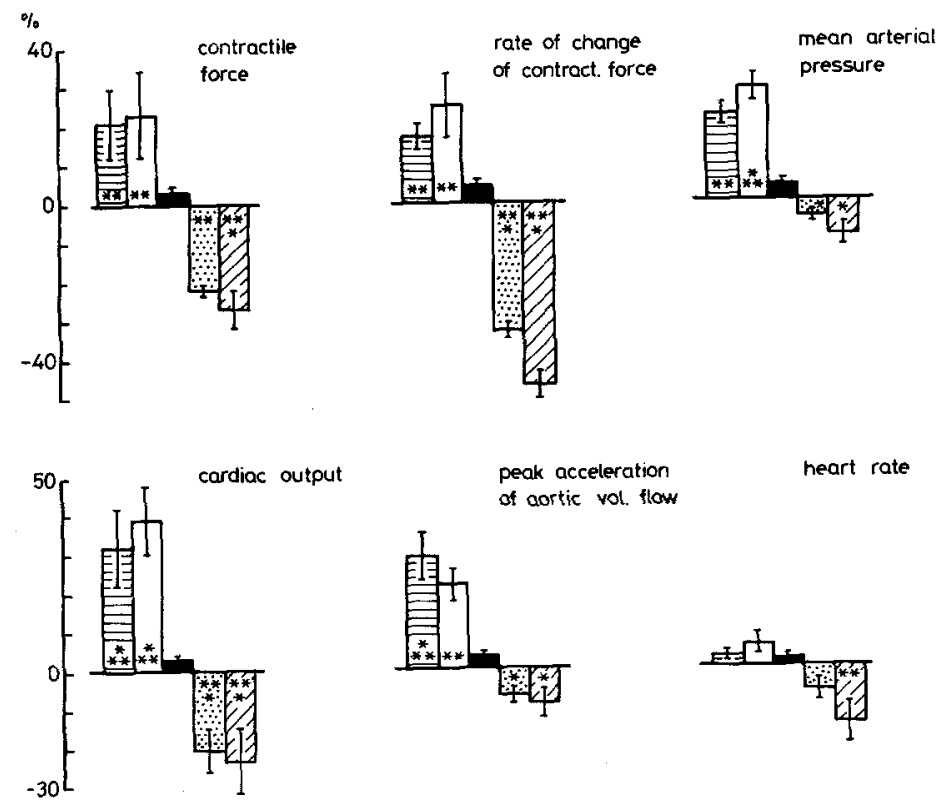

Fig. 2. Change in the myocardial contractile force, rate of change of contractile force, mean arterial pressure, cardiac output, peak acceleration of aortic volume flow and heart rate on carbutamide, on gliclazide, on glibenclamide and on solvents of the drugs in intact animals, expressed as percentage changes. The horizontal lined columns indicate the mean values after administration of $20 \mathrm{mg} / \mathrm{kg}$ carbutamide ( $\mathrm{n}: 8$ ); blank columns those after administration of $5 \mathrm{mg} / \mathrm{kg}$ gliclazide (n:8); black columns those after administration of $1 \mathrm{ml} / \mathrm{kg}$ solvents $(\mathrm{n}: 36)$; dotted columns those after administration of $0.2 \mathrm{mg} / \mathrm{kg}$ glibenclamide $(\mathrm{n}: 6)$; and diagonally lined columns those after administration of $1 \mathrm{mg} / \mathrm{kg}$ glibenclamide (n:6). Other symbols correspond to those used in Figure 1 
tested. The dose of crystalline pork insulin (Actrapid MC, NOVO) was 0.8 units $/ \mathrm{kg}$. The large amount of insulin was used to make changes noticeable if they existed. Each animal received only one kind of drug. Solvents of the sulphonylureas were also tested. These were methylglycamate, polyethyleneglycol or a mixture of polyethyleneglycol and glycerinphormal, all at $\mathrm{pH}$ 7.29. Fifteen intact animals received the solvents of different sulphonylureas only; the solvent of the respective sulphonylurea was also administered to the animal after the lower and higher doses of the respective drug.

Changes of blood sugar levels were also followed during the study. The hypoglycaemic effects of sulphonylureas and insulin was counteracted by the simultaneous administration of glucose. In general $0.5 \mathrm{~g} / \mathrm{kg}$ glucose were administered during the experiment in a solution containing $4 \mathrm{~g}$ glucose $/ 10 \mathrm{ml}$ water, at a rate of $0.2-0.4 \mathrm{ml} / \mathrm{kg} / \mathrm{min}$. Glucose was not administered after pancreatectomy and during solvent administration. Blood sugar was determined with the orthotoluidine method [8]. Statistical analysis was carried out using Student's " $t$ " test.

\section{Results}

The initial and baseline values of the measured parameters are summarized in Table 1 . Despite the fact that the initial values were obtained from different animals, the scatter of these values was slight. The base line values show that the investigated parameters returned to their respective initial levels after the disappearance of drug effect. In Figs. 1 and 2 respectively, the changes produced by the different drugs are indicated in percent of the base line values, in order to illustrate the magnitude of changes in the same dimension.

Haematocrit and arterial oxygen saturation did not change considerably during the experiments. In intact animals blood sugar levels did not change significantly either. After adrenalectomy, in some cases, there was slight hyperglycaemia after administration of the drugs (Table 2). The hypoglycaemic effect of sulphonylurea and insulin was reversed by simultaneously administered glucose; thus the effect of the drugs on the measured parameters was not due to a reduction of the blood sugar level.

Myocardial contractile force as well as the rate of change of myocardial force, arterial blood pressure, cardiac output and peak acceleration of aortic volume flow were significantly enhanced by carbutamide and gliclazide in pancreatectomized and adrenalectomized animals just as in intact ones (Fig. 1). Insulin, even in doses of $0.8 \mathrm{U} / \mathrm{kg}$, and solvents of
Table 1. Initial values of parameters studied and base line values of these parameters fifteen minutes after drug administration in 75 mongrel dogs

\begin{tabular}{|c|c|c|c|}
\hline Parameter & Dimension & $\begin{array}{l}\text { Initial } \\
\text { values } \\
\text { Mean } \pm S E M\end{array}$ & $\begin{array}{l}\text { Base line } \\
\text { values } \\
\text { Mean } \pm \text { SEN }\end{array}$ \\
\hline \multicolumn{4}{|l|}{ Myocardial contractile } \\
\hline force & $\mathrm{g}$ & $34 \pm 1$ & $34 \pm 1$ \\
\hline $\begin{array}{l}\text { Rate of change of } \\
\text { myocardial force }\end{array}$ & g. $\sec ^{-1}$ & $725 \pm 25$ & $718 \pm 42$ \\
\hline Mean arterial pressure & $\mathrm{mm} \mathrm{Hg}$ & $94 \pm 2$ & $90 \pm 2$ \\
\hline Cardiac output & $\mathrm{ml} \cdot \mathrm{min}^{-1} \cdot \mathrm{kg}^{-1}$ & $98 \pm 3$ & $95 \pm 4$ \\
\hline $\begin{array}{l}\text { Peak acceleration of } \\
\text { aortic volume flow }\end{array}$ & ml.sec ${ }^{-2}$ & $6995 \pm 277$ & $6755 \pm 399$ \\
\hline Heart rate & $\min ^{-1}$ & $143 \pm 5$ & $143 \pm 5$ \\
\hline Haematocrit & $\%$ & $41 \pm 1$ & $41 \pm 1$ \\
\hline $\begin{array}{l}\text { Arterial oxygen } \\
\text { saturation }\end{array}$ & $\%$ & $92+1$ & \\
\hline
\end{tabular}

Table 2. Blood sugar values during the study

\begin{tabular}{|c|c|c|c|c|}
\hline & & \multicolumn{3}{|c|}{$\begin{array}{l}\text { Blood sugar } \\
\mathrm{mg} / 100 \mathrm{ml}\end{array}$} \\
\hline & & \multicolumn{3}{|c|}{$\begin{array}{l}\text { Time after } \\
\text { agent (min) }\end{array}$} \\
\hline & & 0 & 5 & 15 \\
\hline \multicolumn{5}{|c|}{ a) Normal animals } \\
\hline \multirow[t]{2}{*}{ glibenclamide } & $0.2 \mathrm{mg} / \mathrm{kg}$ & $84 \pm 5$ & $85 \pm 4$ & $82 \pm 5$ \\
\hline & $1.0 \mathrm{mg} / \mathrm{kg}$ & $83 \pm 4$ & $87 \pm 3$ & $83 \pm 5$ \\
\hline \multirow{2}{*}{ gliclazide } & $5 \mathrm{mg} / \mathrm{kg}$ & $87 \pm 6$ & $88 \pm 7$ & $83 \pm 4$ \\
\hline & $15 \mathrm{mg} / \mathrm{kg}$ & $87 \pm 7$ & $89 \pm 6$ & $89 \pm 10$ \\
\hline \multirow[t]{2}{*}{ carbutamide } & $20 \mathrm{mg} / \mathrm{kg}$ & $84 \pm 7$ & $86 \pm 6$ & $80 \pm 6$ \\
\hline & $80 \mathrm{mg} / \mathrm{kg}$ & $83 \pm 4$ & $85 \pm 4$ & $82 \pm 8$ \\
\hline insulin & $0.8 \mathrm{U} / \mathrm{kg}$ & $87 \pm 10$ & $88 \pm 10$ & $88 \pm 12$ \\
\hline solvent & $1.0 \mathrm{ml} / \mathrm{kg}$ & $88 \pm 3$ & $87 \pm 3$ & $84 \pm 4$ \\
\hline \multicolumn{5}{|c|}{ b) Pancreatectomized animals } \\
\hline gliclazide & $15 \mathrm{mg} / \mathrm{kg}$ & $193 \pm 14$ & $209 \pm 16$ & $203 \pm 13$ \\
\hline carbutamide & $80 \mathrm{mg} / \mathrm{kg}$ & $191 \pm 16$ & $207 \pm 16$ & $212 \pm 17$ \\
\hline solvent & $1.0 \mathrm{ml} / \mathrm{kg}$ & $207 \pm 14$ & $209 \pm 16$ & $217 \pm 14$ \\
\hline \multicolumn{5}{|c|}{ c) Adrenalectomized animals } \\
\hline gliclazide & $15 \mathrm{~m} / \mathrm{kg}$ & $93 \pm 3$ & $115 \pm 11$ & $105 \pm 9$ \\
\hline carbutamide & $80 \mathrm{mg} / \mathrm{kg}$ & $84 \pm 7$ & $89 \pm 10$ & $84 \pm 10$ \\
\hline solvent & $1.0 \mathrm{ml} / \mathrm{kg}$ & $86 \pm 7$ & $89 \pm 5$ & $87 \pm 4$ \\
\hline
\end{tabular}

sulphonylureas did not induce any changes (Fig. 1). Total pancreatectomy and adrenalectomy did not alter the cardiovascular effects of carbutamide and gliclazide, and insulin had no noticeable effect on cardiovascular function.

The lower doses of carbutamide and gliclazide significantly enhanced myocardial contractile force, rate of change of myocardial force, arterial blood pressure, cardiac output and peak acceleration of aortic volume flow (Fig. 2). Glibenclamide, on the other hand, at both doses studied markedly decreased these parameters (Fig. 2). Blood glucose 
changes were the same with all drugs (mean maximal change $6 \mathrm{mg} / 100 \mathrm{ml}$ with carbutamide, $5 \mathrm{mg} / 100 \mathrm{ml}$ with gliclazide, and 3 and $4 \mathrm{mg} / 100 \mathrm{ml}$ with the two doses of glibenclamide). Thus, glibenclamide had significantly different effects from gliclazide and carbutamide.

\section{Discussion}

From the pioneer work of Levey et al. [10] and subsequent observations $[3,5,9,11,15,17]$ it is well known that certain hypoglycaemic sulphonylureas are able to increase myocardial contractile force, enhance the automaticity of Purkinje fibres and elevate arterial blood pressure. However, in the intact dog Lucchesi et al. [12] could not demonstrate alterations in cardiovascular dynamics, including myocardial contractility, cardiac output and coronary blood flow, after intravenous administration of tolbutamide, even at a dose sufficient to raise the plasma concentration to $10 \mathrm{mg} / 100 \mathrm{ml}$. Furthermore, Curtis et al. [5] were unable to demonstrate a positive inotropic effect of tolbutamide either on isolated canine papillary muscle or on intact canine heart. Roth et al. [15], as well as Crockett et al. [4] and Young et al. [18], also could not confirm a positive inotropic effect of tolbutamide on human papillary muscles or in intact man. These studies suggest that tolbutamide exerts positive inotropic effects only in rabbits, cats and rats, whereas human and dog myocardial tissue is unresponsive to the drug [5]. As revealed by our present study gliclazide and carbutamide increase myocardial contractile force and blood pressure in the intact dog. Nevertheless, the question arises whether or not in the intact dog insulin, glucagon or catecholamines mediate the positive inotropic and hypertensive effects of gliclazide and carbutamide. The observations were repeated, therefore, on pancreatectomized and adrenalectomized dogs. These investigations excluded the possibility that insulin, glucagon, adrenaline or cortisol play any role in the positive inotropic and hypertensive effects of gliclazide and carbutamide. The possible intervention of noradrenaline could not be excluded since the heart is able to synthesise and store noradrenaline and this ability is independent of the function of the adrenal medulla.

Glibenclamide however, has opposite actions, reducing myocardial contractile force and blood pressure. Moreover, glibenclamide differs from other sulphonylureas in other respects, too. Unlike tolbutamide and chlorpropamide, glibenclamide increases rather than reduces diuresis in diabetics [6] and polyuria in diabetes insipidus [14]. The reason why glibenclamide has such different effects is not known.

Since the study of the University Group Diabetes Program [16] it is a well known but disputed hypothesis $[1,5,11]$ that cardiovascular mortality may be increased by tolbutamide. The positive inotropic effect of sulphonylureas - as demonstrated on animals - may be of paramount importance in this respect. It is well known that myocardial work and oxygen consumption are increased by agents which enhance myocardial contractility, such as catecholamines [7] and digitalis [2]. Furthermore, inotropic agents administered to dogs prior to experimental coronary occlusion increase both the severity and extent of the myocardial injury [13]. It is evident, at the same time, that information obtained on animals cannot be extrapolated to man. There is also much evidence against the conclusions of the University Group Diabetes Program. Nevertheless, it is interesting that of the large family of hypoglycaemic sulphonylureas only glibenclamide has been found - up to the present - to reduce myocardial contractility and arterial blood pressure.

\section{References}

1. Bradley, R.F., Dolger, H., Forsham, P.H., Seltzer, H.: Settling the UGDP controversy? J. A. M. A. 232, 813-817 (1975)

2. Covell, J. W., Braunwald, E., Ross, J. jr., Sonnenblick, E. H.: Studies on digitalis. XVI. Effects on myocardial oxygen consumption. J. Clin. Invest. 45, 1535-1542 (1966)

3. Crass III, M.F., Spanheimer, R. G., Stone, D.B., Brown II, R. J.: Tolbutamide-induced inotropic responses in the perfused working heart: effects of albumin. Proc. Soc. Exp. Biol. Med. 142, 861-866 (1973)

4. Crockett, S. E., Marsh, D., Lewis, R. P., Tzagournis, M.: Lack of cardiac inotropic effect of tolbutamide in intact man. Metabolism 23, 763-769 (1974)

5. Curtis, G.P., Setchfield, J., Lucchesi, B. R.: The cardiac pharmacology of tolbutamide. J. Pharmacol. Exp. Ther. 194, 264-273 (1975)

6. Garcia, M., Miller, M., Moses, A. M.: Chlorpropamide-induced water retention in patients with diabetes mellitus. Ann. Intern. Med. 75, 549-553 (1971)

7. Graham, T.P. jr., Covell, J.W., Sonnenblick, E.H., Ross, J. jr., Braunwald, E.: Control of myocardial oxygen consumption: relative influence of contractile state and tension development. J. Clin. Invest. 47, 375-385 (1968)

8. Hyvärinen, A., Nikkilä, E. A.: Specific determination of blood glucose with o-toluidine. Clin. Chim. Acta 7, 140-143 (1962)

9. Lasseter, K. C., Levey, G. S., Palmer, R.F., McCarthy, J.S.: The effect of sulfonylurea drugs on rabbit myocardial contractility, canine Purkinje fiber automaticity, and adenyl cyclase activity from rabbit and human hearts. J. Clin. Invest. 51, 2429-2434 (1972)

10. Levey, G. S., Palmer, R. F., Lasseter, K. C., McCarthy, J.: Effects of tolbutamide on adenyl cyclase in rabbit and human heart and contractility of isolated rabbit atria. J. Clin. Endocrinol. Metab. 33, 371-374 (1971) 
11. Levey, G. S., Lasseter, K. C., Palmer, R. F.: Sulfonylureas and the heart. Annu. Rev. Med. 25, 69-74 (1974)

12. Lucchesi, B. R., Curtis, G.P., Lomas, T., Setchfield, J.: The effects of tolbutamide on cardiac contractility and coronary blood flow in the canine heart. Univ. Mich. Med. Cent. J. 39, 30-34 (1973)

13. Maroko, P.R., Kjekshus, J.K., Sobel, B.E., Watanabe, T., Covell, J. W., Ross, J., Braunwald, E.: Factors influencing infarct size following experimental coronary artery occlusions. Circulation 43, 67-82 (1971)

14. Radó, J. P., Borbély, L.: Enhancement of polyuria by glibenclamide in diabetes insipidus. Lancet 1971 II, 216

15. Roth, J., Prout, T.E., Goldfine, I.D., Wolfe, S.M., Muenzer, J., Grauer, L.E., Marcus, M. L.: Sulfonylureas: Effects in vivo and in vitro. Ann. Intern. Med. 75, 607-621 (1971)

16. The University Group Diabetes Program: A study of the effects of hypoglycemic agents on vascular complications in patients with adult-onset diabetes. II. Mortality results. Diabetes 19 (Suppl. II), 789-830 (1970)
17. Wales, J. K., Grant, A.M., Wolff, F. W.: The effect of tolbutamide on blood pressure. J. Pharmacol. Exp. Ther. 178, 130-140 (1971)

18. Young, J. L. jr., Burr, I. M., Perry, J.M., Nelson, J.H., Nies, A.S.: Inotropic effects of tolbutamide in man. Am. Heart J. 89, 189-194 (1975)

Received: February 8, 1977, and in revised form: May 16, 1977

Dr. G. Pogátsa

Research Unit

National Institute of Cardiology

P. O. B. $9-88$

Hámán Kató utca 29

H-1450 Budapest

Hungary 